\title{
Ethical Education and Sensitivity of Students in Kenule Beeson Saro Wiwa Polytechnic, Nigeria: The Role of Value and Relevance
}

\author{
${ }^{1}$ Ferry Barineka Gberegbe, ${ }^{2}$ Gabriel Asunomeh Idornigie, \\ ${ }^{3}$ Lilian Okorite Nkanbia-Davies \\ ${ }^{123}$, Department Of Accountancy Kenule Saro Wiwa Polytechnic Bori Rivers State
}

\begin{abstract}
:
Purpose: This study investigated the relationship between value, relevance and ethical sensitivity of students in a sample of 350 Business, Science and Engineering students from Ken Saro Wiwa Polytechnic, Bori. It examined the association between personal benefit and ethical sensitivity of Ken Saro Wiwa students in Nigeria. Design/Methodology/Approach: This is an exploratory study that adopted the quantitative research approach in investigating the assumed relationship between personal benefit, value, relevance and ethical sensitivity of students in Ken Saro Wiwa Polytechnic, Bori.

Findings: Personal benefits, value, and relevance are positively associated with the ethical sensitivity of students in Nigeria. This study indicates that the ethical sensitivity of students will increase with the level of personal benefit identified in a particular circumstance.

Originality/Value: To the best of our knowledge, we do not know of any study that has investigated the relationship between personal benefit, value, relevance and ethical sensitivity of students in Nigeria. Thus, this study fills the gap in existing literature and provides a guide for formulating ethical policy for students in Nigeria.
\end{abstract}

Key words: Value, Relevance and ethical sensitivity.

\section{Introduction}

The recent financial restatements made by Enron, Worldcom and Tyco (Eichenwald, 2012) and several corporate failures and scandals in the United State (US), Australia, Europe and Africa have prompted increased public scrutiny of businesses (Sugahara and Boland, 2011, Martinov-Bennie and Mladenovic, 2015). The reputation of business has been besmirched with the continuous barrage of corporate scandals which have widespread economic recession (Reich, 2011) and have significantly influenced global economic activities (Lowenstein, 2011). Consequently, business is now perceived by the public as a scourge and ethically challenged (Warnell, 2011). According to Cavanagh (2009), the leaders responsible for these scandals are graduates of our best business programmes. This suggests that many of todays most highly regarded business schools appear to have failed to convey ethics and good moral habits to their graduates. Further, the presence of cheating culture (Callahan, 2004) appears to have created a global crisis of confidence (Walker, Paletta, Blackstome, Gongloff and Vierra, 2011) and lack of trust on business leaders in the society.

Consequently, several management scholars has advocated for a change in approach to the study of ethics such that it will results to meaningful changes. The academic community has recognized the need to develop a range of ethical values and have suggested that technical excellence should be developed with ethical expectations (Molyneaux, 2004). Similarly, Eichenwald (2002) argued that one way to influence integrity in business is by raising ethical sensitivity in leaders while they are college students. An individual's ability to identify that a situation has ethical context when it is encountered, is a necessary antecedent to an individual's consideration of a situation from an ethical perspective (Myyry and Helkama, 2002).

Several studies (Sims and Felton, 2006, Cooper, Leung, Dellaportas, Jackling and Wong, 2008; Datar, Garvin and Cullen, 2010; Sims and Sauser, 2011; Martinov-Bennie and Mladenovic, 2015) support the development of business students' ethical sensitivity and the ability to make decisions with respect to ethical issues. According to Early and Kelly (2004), this is an important way of reducing future judgment errors in business and decisions that stimulate positive values in the society. Cooper et al. (2008) asserts that ethics education is a deliberate attempt designed to promote ethical awareness and judgment. Also, the Association to Advance Collegiate Schools of Business (AACSB, 2004) argues that ethics education should enhance students' ability to recognize ethical issues and enhance their ethical sensitivity and awareness.

According to Saat (2010), from childhood a person is taught what is morally good or bad and faces many experiences that identify the difference between right and wrong. Nevertheless, as people grow older, morality appears to be situational and the line between right and wrong some time blurs when individual needs 
and desires to take precedence over normal principles. Ethics permeate all aspect of lives; thus, it is important that an individual's moral education is reinforced at every stage of live. Weaver (2007) argues that the identification of an individual's component of cognition, affect, skill, responsibility and knowledge may assist him/her to gauge the nature of ethics.

Further, because competence cannot be purchased anywhere, it is important to raise students' ethical sensitivity. Ethical sensitivity is a behavioural and emerging concept that represents an aspect of decision making in the society (Weaver, 2007). It includes being aware of those that are concerned in a situation, which lines of action are possible as well as what might be the outcome of different behaviours to different parties. An individual has the potential to recognize that there is a moral issue in a situation or recognizes the ethical context of a decision situation or that serves as a means of triggering mechanism that begins the ethical decision making process. Thus, improving students' ethical sensitivity will stimulate the development of their cognitive framework in a way that assists to facilitate students' ability in identifying ethical dilemmas that they may encounter as they progress in their career (Coyne, Massey and Thibodeau, 2005)

Although the process allows an individual to take a particular role, it is important that such individual recognize that violating some moral norms, or allowing unethical situations to occur, can affect the needs, welfare, interest and expectation of others (Rest, 1994). In addition, everyone has the ability to interpret situations. However, there is suggestion that ethical sensitivity is context specific. That is, an individual who displays great ethical sensitivity in one situation may be quite ethically insensitivity in another. This is as a result of the difference an individual exercise role-taking when confronted with ethical situations.

Rest, by measuring ethical sensitivity contributed to its development by revealing its usefulness to the society. However, it has received little attention (Myyry and Helkama. 2002).

The purpose of this study is to determine the relationship between value, relevance and ethical sensitivity in Nigeria. Also, it aims at assessing the relationship between personal benefits (or loss) and ethical sensitivity of students in Nigeria. First Ethical sensitivity is examined and a review of literature is provided. Next, an exploratory analysis of students' sensitivity is conducted with the aim of strengthening its understanding within Nigeria context. Finally, deductions is drawn from the findings and recommendation was made.

\subsection{Ethical sensitivity}

\section{Conceptual framework}

According to Martinov-Bennie and Mladenovic (2015), ethical sensitivity refers to the interpretation of a particular situation, recognition of the ethical issues, awareness of what actions are possible and the effect on the parties' concerned (p. 190). Ethical issues are understood in terms of values or concerns such as public safety, economic security, fairness, honesty or truthfulness (McClagan 2003). Accordingly, AACSB (2004) asserts that learning experienced should be integrated into ethical decision making because it influences student's ability to identify ethical issues and ethical sensitivity. If every decision has an ethical dimension, students should be sensitized.

There are several methods that could be used to influence student's ethical decision process. On one hand, business educators might allow the students to read and participate in lecture to develop their ethical sensitivity. On the other hand, business educators might use case analysis and class discussion in developing their ethical sensitivity. Despite the fear of personal consequences of unethical behaviour, case studies investigating the consequences of real-life behaviour can be an effective mechanism to impact change.

\subsubsection{Value relevance approach $(\mathrm{VRA})$}

VRA is a promising training method that could be used to develop students' ethical sensitivity. According to Coyne etal. (2000), VRA employs active instructional techniques to demonstrate the costs (benefits) associated with unethical (ethical) conduct it precedes the stage of initiating ethical decisions and can assist students develop cognitive frameworks that can enable them identify and resolve ethical issues, which they may encounter in the future.

\section{The role of value}

Values are goals and motivations that guide the way people live. It can be divided into two groups according to whether they serve individual or collective interest (Myyry, Juujarvi and Pesso, 2010). Power, achievement, stimulation and self direction are values that serve individual interest where as tradition, benevolence and confirmty serve common interest.

It is a dominant force in life that directs an individual activity. There are claims that values intimately bound up within an individual sense of self and as a type of personality disposition. In addition, there are suggestions that people's valued priorities may influence the understanding and predicting their attitudinal and 
behavioural decisions. Thus, Myyry etal (2010) asserts that values, which are connected to an individual's identity should serve as a motivational force that affect behaviour, evaluation and in choosing alternatives.

Coyne etal. (2005) explain that the first tenet of VRA emphasized on the notion that value is influenced by both ethical and unethical conduct. They stressed that by acting in an ethical manner stimulates professional value in today's knowledge and relationship-based economy. Similarly, unethical conduct (for example, fraudulent action) may lead to significant human and financial costs to individuals, organizations and the society.

Accordingly, the information value chain may assists to establish the relationship between value and ethical or unethical conduct. The value added role individuals is to deliver critical knowledge at the point-ofneed for managers and investors with trust worthiness and unbreachable integrity (Elliot, 2000). Once there is no assurance of reliance on their decision, the services provided by these people are not likely to be trusted. Therefore, the value of such person diminishes because of unethical conduct. Lack of trust will result in loss in value in an economy where the main value driver is knowledge and relationship.

\section{The role of relevance}

The importance of relevance in the development of ethical sensitivity has been acknowledged in VRA. Coyne etal (2005) illustrates relevant cases, presenting it using active learning approach and feedback. An important feature of VRA is the use of real world examples in learning activity. Therefore, integrating direct experience with reflection may be useful in developing cognitive framework of understanding ethical issues. They argue that ethical intervention will assists students develop a cognitive framework of understanding. Thus, assume that the use of relevant cases is important in developing students' ethical sensitivity.

\subsection{Empirical review}

Most of the studies investigating the development of ethical sensitivity are rooted in the cognitivedevelopment perspective (Rest 1994). The cognitive-development perspective focuses on the cognitive and developmental nature of the reasoning structures that precipitate ethical choices. Rest model of ethical action provides as follows: (1) Identification of ethical dilemma, (2) Formulation of ethical judgement, (3) Identification of an intention to act ethically, and (4) ethical action/behaviour of particular relevance to the development of business students ethical action is their ethical sensitivity. This is likely to influence students' ability to identify situations and would initiate the ethical decision process (Armstrong, Ketz and Owsen, 2003).

Research on the effectiveness of ethics education on the development of ethical sensitivity is mixed. McManus and Subramanian (2009) revealed that ethic education significantly influence the perceptions of the severity of an ethical issue and the ethical judgements of business students. Lau (2010) indicates that business students that received ethics education exhibit greater ethical sensitivity relating to business and personal situations. Similarly, Chan and Leung (2006) suggest that ethics intervention may have positive influence on student's ethical sensitivity development. Nevertheless, Ozdogan and Eser (2007) showed that ethics education had no significant influence on ethical sensitivity and that students had lower ethical sensitivity. This result could be as a result of situational and personal factors.

Two questions about ethical sensitivity have so far been inadequately addressed: Does value and or relevance influence ethical sensitivity of students in Nigeria? What is the relationship between personal benefits (or loss) and ethical sensitivity of students in Nigeria? Available studies indicate that ethical sensitivity is influence by situations and individual understanding of the concept. Therefore, further analysis is needed to determine if value and or relevance influence ethical sensitivity of students in Nigeria.

The above relationship is hypothesized as follows:

HO1- Value and or relevance does not significantly influence the ethical sensitivity of students in Nigeria. HO2- Personal benefits (or loss) do not significantly influence the ethical sensitivity of students in Nigeria

\subsection{Theoretical framework}

The theoretical model of ethical decision making was developed since the late 1980s in the business ethics literature. According to Rest and Narvaez (1994), the basis of these theoretical models of ethical decision making has been drawn mainly from Psychology and extended into business. Rest (1986 cited in MartinovBennie and Mladenovic 2015) four component model provides the foundation of other models of ethical decision (see fig. 1). It specifies four different processes individuals must take in order to integrate ethical dimensions in their decisions and behaviour (Cohen and Martinov-Bennie 2006). First, ethical sensitivity should enable an individual interprets a particular situation, recognize ethical issues, and be aware of what actions are possible and the effect on the parties involved. Secondly, there should be ethical judgement (reasoning). This process is about what ought to be done, that is, which course of action is ethically justifiable. Thirdly, there should be ethical motivation. Once ethical intent is established, the individual will prioritize ethical values over other values. Finally, the individual should be engaged in ethical behaviour such that there would be 
perseverance. However, for this study, we will focus on ethical sensitivity and making ethical judgement about which course of action is more ethically justifiable. Ethical sensitivity and judgement are critical to ethical decision-making processes. Similarly, Cooper et al. (2008) argued that students' ethical sensitivity and judgement can be enhanced through the education process.

\section{Method}

An exploratory design was adopted for this study. Using a convenience sample, 350 Business, Science, Engineering and Environmental Technology students were randomly selected. The criteria for the selection of the participants are:1) Students that are not in year one in Tertiary institution, and 2) ability to answer questions in a consistent manner. Participation was voluntary. The participants filled out the questionnaire after an interactive session with the authors. The authors used the session to illustrate several cases of unethical conduct in Nigeria (for example, the subsidy scam in the oil industry and cases of bank failures due to window dressing and false representation).

The questionnaire consist of five parts:1) demographic, 2) personal benefit, 3) relevance, 4) value and ethical sensitivity. To measure the level of ethical sensitivity, the questionnaire is used with 5 -points, agreeddisagreed Likert-Scale questions. Personal benefit was measured in terms of harm and risk associated with interrelationship. Similarly, value was measured in terms of dignity and welfare of others, sacrifice, moral actions and principles of ethics. Finally, relevance was defined by consequences of actions, physical harm and the welfare of others.

\section{Results}

Table 1: Bivariate correlation between pesonal benefits relevances, value and ethical sensitivity.

\begin{tabular}{|l|l|l|l|l|}
\hline & $\mathbf{P B}$ & $\mathbf{R}$ & $\mathbf{V}$ & $\mathbf{E S}$ \\
\hline PB & 1 & & & \\
\hline R & $0.438^{* *}$ & 1 & & \\
\hline V & $0.368^{* *}$ & $0.352^{* *}$ & 1 & \\
\hline ES & $0.436^{* *}$ & $0.459^{* *}$ & $0.428^{* *}$ & 1 \\
\hline
\end{tabular}

$P B=$ Personal benefits, $R=$ relevance, $V=$ values, $E S=$ ethical sensitivity, $* *$ significant at $1 \%(p<0.01)$.

Table 1 shows that the bivariaet relationship between the three independent variables personal benefit, relevance, values and ethical sensitivity. It indicates a positive relationship between personal benefit $(r=0.438$, $\mathrm{p}<0.001)$, relevance $(\mathrm{r}=0.459, \mathrm{p}<0.001)$, value $(\mathrm{r}=0.428, \mathrm{p}<0.001)$ and ethical sensitivity. This result implies that the more the personal benefit, value and relevance are identified in a situation the higher the level of ethical sensitivity.

Table 2: Multiple regression showing the contribution of personal benefit, relevance, and value on ethical sensitivity

\begin{tabular}{|l|l|l|l|l|l|l|l|}
\hline Variables & $\begin{array}{l}\text { Standardized } \\
(\boldsymbol{\beta})\end{array}$ & $\begin{array}{l}\text { Standard } \\
\text { Error }\end{array}$ & t-value & P-value & $\mathbf{R}^{2}$ & $\mathbf{F}$ \\
\hline Personal benefit & 0.223 & 0.053 & 4.22 & $0.000^{* *}$ & 0.576 & $52.40^{* *}$ & $<0.01$ \\
\hline Relevance & 0.252 & 0.073 & 5.23 & $0.000^{* *}$ & & & \\
\hline Values & 0.274 & 0.059 & 4.96 & $0.000^{* *}$ & & & \\
\hline
\end{tabular}

\footnotetext{
**significant at $1 \%(p<0.01)$
}

The Table above reveals a joint positive influence of personal benefit, relevance and values on ethical sensitivity of, $\mathrm{F}=52.40, \mathrm{p}<0.05$. Also it yielded a coefficient of determination of 0.576 , which means that 57.6 percent of the variation in students' ethical sensitivity was accounted for by personal benefit, relevance and values. Also, in terms of individual influence, the result shows that personal benefit ( $\beta=0.223, \mathrm{t}=4.22, \mathrm{p}<0.05$ ), relevance ( $\beta=0.252, \mathrm{t}=5.23, \mathrm{p}<0.05)$ and values $(\beta=0.274, \mathrm{p}<0.05)$. This therefore means that personal benefit, relevance and values have positive contribution to ethical sensitivity of the respondents.

\section{Conclusion}

Previous studies on the effectiveness of ethics education and the development of ethical sensitivity suggested different outcome. McManus and Subramanian (2009) revealed that ethic education significantly influence the perceptions of the severity of an ethical issue and the ethical judgements of business students. Lau (2010) have shown that business students that received ethics education exhibit greater ethical sensitivity relating to business and personal situations. In a related study, Chan and Leung (2006) opined that ethics intervention may have positive association with student's ethical sensitivity development. However,, Ozdogan and Eser (2007) revealed that ethics education had no significant influence on ethical sensitivity and that 
students had lower ethical sensitivity. As mentioned earlier, the differences in outcome could be as a result of differences in circumstance.

The result of our study indicates that personal benefits, value and relevance significantly influence ethical sensitivity of students in Nigeria. The positive values of the three independent variables (personal benefit, value and relevance) show that they can be used to develop ethical sensitivity of students.

\section{Limitation and Recommendation}

Although the Cronbach Alpha reliability test yielded a coefficient of 0.77 , which is appropriate for taking decision. However, this study is limited by its approach and scope. Further, the correlated data does not allow for the causal interpretation of results. Therefore, it is recommended that further study be conducted, which will address the limitations imposed by the method used, the scope and causality.

\section{References}

[1]. Abdolmohammadi, M. and Owhoso, V. (2000). Auditors' Ethical Sensitivity and Assessment of the Likelihood of Fraud, Managerial Finance, 26:21-29.

[2]. Armstrong, M.; Ketz, E. and Owsen, D. (2003). Ethics Education in Accounting: Moving toward Ethical Motivation and Ethical Behaviour, Journal of Accounting Education, 21:1-16.

[3]. Association to Advance Collegiate Schools of Business (2004). Ethics Education in Business Schools: Report of the Ethics Education Taskforce to ACCSB International Board of Directors. St. Louis, Mo: AACSB.

[4]. Badaracco, J.L. (1997). Defining Moments: When Managers must choose Between Right and Right. Boston, MA: Haward Business School Press.

[5]. Bowen, P. and Smythe, V. (2008). Theories on Teaching and Training in Ethics, Electronic Journal of Business Ethics and organizational Studies, 13(2):19-26.

[6]. Brytting, T. (2002). Moral Competence: A Non Relativistic, Non-Rationalistic Definition, in H. Von Weltzien Hoivik (Ed), Moral Leadership in Action. Cheltenhan: Edward Elgar.

[7]. Buff, L.C. and Yonkers, V. (2005). Using Student Generated Codes of Conduct in the Classroom to Reinforce Business Ethics Education, Journal of Business Ethics, 61:101-110.

[8]. Burke, J.A.; Polimeni, R.S. and Slavin, N.S. (2007). Academic Dishonesty: A Crisis on Campus, CPA Journal, 77(5):58-65.

[9]. Caldwell, C.; Truong, O.; Linh, P. and Tuan, A. (2011). Strategic Human Resources Management as Ethical Stewardship, Journal of Business Ethics, 98(1):171-182.

[10]. Callahan, D. (2004). The Cheating Culture: Why more Americans are doing wrong to get Ahead. Orlando, FL: Mariner Books.

[11]. Cavanagh, G.F. (2009). What's good for Business?, America, 20(4):20-22.

[12]. Chan, S.Y.S. and Leung, P. (2006). The Effects of Accounting Students' Ethical Reasoning and Personal Factors on their Ethical Sensitivity, Managerial Auditing Journal, 21(4):436-457.

[13]. Collins, J. and Porras, J.I. (2004). Built to Last: Successful Habits of Visionary Companies. New York: Harpe Collins Publishing.

[14]. Comer, D.R. and Vega, G. (2005). An Experimental Exercise that Introduces the Concept of Personal Ethical Threshold to Develop Moral Courage, Journal of Business Ethics Education, 2(2):171-197.

[15]. Cooper, B.J.; Leung, P.; Dellaportas, D.; Jackling, B. and Wong, G. (2008). Ethics Education for Accounting Students: A Toolkit Approach, Accounting Education: An International Journal, 17(4):405-430.

[16]. Coyne,P.M., Massey,.W.D and Thibodeau,C.J (2005). Raising students ethical sensitivity with a value relevance approach,Advances in Accounting Education: Taeching and Curriculum Innovations, 7:171-205

[17]. Datar, S.M.; Garvin, D.A. and Cullen, P.G. (2010). Rethinking the MBA: Business Education at a Cross Roads. Boston, M.A: Harvard Business School Publishing.

[18]. Earley, C.E. and Kelly, P.T. (2004). A Note on Ethics Educational Interaction in an Undergraduate Auditing Course. Is there an 'Enron Effect'? Issues in Accounting Education, 19(1):53-71.

[19]. Eichenwald, K. (2002). Even if Heads Roll, Mistrust will live on. New York Times. October 6.

[20]. Elm, D.R. and Radin, T.J. (2012). Ethical Decision Making: Special or no Different?, Journal of Business Ethics, 107(3):313-329.

[21]. Farrell, B.; Cobbin, D. and Farrell, H. (2002). Can Codes of Ethics Really Produce Consistent Behaviours, Journal of Management Psychology 17(6):468-491.

[22]. Fink, L.D. (2003). Creating Significant Learning Experiences: An Integrated Approach to Design College Courses. San Francisco, CA: Jossey-Bass.

[23]. Fisscher, O.; Nyhof, A. and Steensma, H. (2003). Dynamics in Responsible Behaviour in Search of Mechanisms for Coping with Responsibility, Journal of Business Ethics, 44(2):209-223.

[24]. Floyd, A.L.; Xu, F.; Atkins, R. and Caldwell, C. (2013). Ethical Outcomes and Business Ethics: Toward Improving Business Ethics Education, Journal of Business Ethics, 117:753-776.

[25]. Garcia-Marza, D. (2005). Trust and Dialogue: Theoretical Approach to Ethics Auditing, Journal of Business Ethics, 57:209-219.

[26]. Gautschi, H. F and Jones, M. T (1998). Enhancing the Ability of Business Students to Recognize Ethical Issues: An Empirical Assessment of the Effectiveness of a Course in Business Ethics, Journal of Business Ethics, 17: 205 - 216.

[27]. Ghoshal, S. (2005). 'Bad Management Theories are Destroying Good Management Practices, Academy of Management and Education, 4(1):75-91.

[28]. Green, S. and Weber, J. (1997). Influencing Ethical Development: Exposing Students to the AICPA Code of Conduct, Journal Business Ethics, 16(8):77-790.

[29]. Harrington, S.J. (1996). The Effect of Codes of Ethics and Personal Denial of Responsibility on Computer Abuse Judgments and Intentions, MIS Quarterly, 20(3):257-278.

[30]. Herndon, N.C.; Fraedrich, J.P. and Yeh, O. (2001). An Investigation of Moral Values and the Ethical Content of the Corporate Culture: Taiwanese Versus U.S. Sales People, Journal of Business Ethics, 30:73-85.

[31]. Hill, P.R. and Rapp, J.M. (2014). Codes of Ethical Conduct: A Bottom-up Approach, Journal of Business Ethics, 123:621-630.

[32]. Hoivik, W.H. (2009). Developing Students' Competence for Ethical Reflection while Attending Business School, Journal of Business Ethics, 88:5-9.

[33]. Hunt, S.D. and Vifell, S.J. (1986). A General Theory of Marketing Ethics, Journal of Macro Marketing, 8(2):5-16.

[34]. Jeurissen, R. (2000). The Social Function of Business Ethics, Business Ethics Quarterly, 10(4):821-843. 
[35]. Jones, G. and Kavanagh, M. (1996). An Experimental Examination of the Effects of Individual and Situational Factors on Unethical Behavioural Intentions in the Workplace, Journal of Business Ethics, 15:511-523.

[36]. Kidwell, L.A. (2001). Student Honour Codes as a tool for Teaching Professional Ethics, Journal of Business Ethics, 29:45-49.

[37]. Lau, C.L.L. (2010). A Step Forward: Ethics Education Matters, Journal of Business Ethics, 92(4):565-584.

[38]. Lowenstein, R. (2011). The End of Wall Street. New York: The Penguin Press.

[39]. Maclagan, P. (2003). Varieties of Moral Issue and Dilemma: A Framework for the Analysis of Case Material in Business Ethics Education, Journal of Business Ethics, 48:21-32.

[40]. Martin, K. and Parma, B. (2012). Assumptions in Decision Making Scholarship: Implications for Business Ethics Research, Journal of Business Ethics, 105(3):289-306.

[41]. Martinov-Bennie, N. and Mladenovic, R. (2015). Investigation of the Impact of an Ethical Framework and an Integrated Ethics Education on Accounting Students' Ethical Sensitivity and Judgment, Journal of Business Ethics, 127:189-203.

[42]. McCabe, D.L.; Trevino, L. and Butte-field, K.D. (1999). Academic Integrity in Honour Code and Non-Honour Code Environment: A Qualitative Investigation, the Journal of Higher Education, 70(2):211-234.

[43]. McLean, B. and Elkind, P. (2003). The Smartest guys in the Room: The Amazing Rise and Scandalous Fall of Enron. New York: Penguin.

[44]. McManus, L. and Subramaniam, N. (2009). Ethical Evaluations and Behavioural Intentions of Early Career Accountants: The Impact of Mentors, Peers, and Individual Attributes, Accounting and Finance, 49(3):619-643.

[45]. Mdyneaux, D. (2004). After Andersen: An Experience of Integrating Ethics into Undergraduate Accountancy Education, Journal of Business Ethics, 54(4):385-398.

[46]. Mele, D. (2005). Ethical Education in Accounting: Integrating Rules, Values and Virtues, Journal of Business Ethics, 57(1):97-109.

[47]. Myyry, L. and Helkama, K. (2002). The Role of Value Priorities and Professional Ethics Training in Moral Sensitivity, Journal of Moral Education, 31(1):35-50.

[48]. Myyry,L., Juujarvi,S and Pesso, K (2010). Empathy,perspective taking and personal values as predictors of moral schemas, Journal of Moral Education,39(2):213-233

[49]. Ozdogam, F.B. and Eser, Z. (2007). Ethical Sensitivity of College Students in a Developing Country: Do Demographic Factors Matter?, Journal of Teaching in International Business, 19(1):83-99.

[50]. Paine, L.S. (2003). Value Shift: Why Companies must Merge Social and Financial Imperatives to Achieve Superior Performance. New York: McGraw Hill.

[51]. Park, H.J. (1998). Can Business Ethics be Taught? A New Model of Business Ethics Education, Journal of Business Ethics, 17:965977.

[52]. Peppas, S. and Diskin, S. (2001). College Courses in Ethics: Do they really make a Difference? The International Journal of Educational Management, 15(6/7):347-353.

[53]. Ravenscroft, S. and Dillard, J. (2008). Moral Imagining: Toward using Cognitive Science in Teaching Business Ethics. In D.L. Swanson and D.G. Fisher (Eds), Advancing Business Ethics Education. Charloffe, NC: Information Age Publishing.

[54]. RedEye, A.N. (2003). Faking the Grade Cheating goes High-Tech, puts Schools to the test. Chicago: Chicago Tribune.

[55]. Reich, R.B. (2011). Aftershock; the Next Economy and America's Future. New York: Picador.

[56]. Rest, J.R. and Narvaez, D. (1994). Moral Development in the Profession: Psychology and Applied Ethics. Hillsdale, NJ: L. Erbaum Associates.

[57]. Rosthorn, J. (2000). Business Ethics Auditing-more than a Stakeholder's Toy, Journal of Business Ethics, 27:9-19.

[58]. Saat,M.M (2010).A $n$ investigation of the effect of a moral education programme on the ethical development of Malaysian future Accountants. Unpublished Doctor Dissertation. Curtis: Curtis University of Technology.

[59]. Schwartz, M.S. (2002). A Code of Ethics for Corporate Code of Ethics, Journal of Business Ethics, 41:27-43.

[60]. Shaub, M. (1989). An Empirical Examination of the Determinants of Auditors Ethical Sensitivity. Unpublished Doctoral Dissertation. Lubbock's, Texas: Texas Tech. University.

[61]. Sims, R. and Felton, E. (2006). Designing and Delivering Business Ethics Teaching and Learning, Journal of Business Ethics, 63(3):297-312.

[62]. Sims, R.L. and Keon, T.L. (1999). Determinants of Ethical Decision making: The Relationships of the Perceived Organizational Environment, Journal of Business Ethics, 19:393-401.

[63]. Sims, R.R. (2002). Teaching Business Ethics for Effective Learning. Westport CT,: Quorum Books.

[64]. Sims, R.R. and Sauser, W.I. (2011). Experience in Teaching Organization. New York: Doubleday.

[65]. Steven, B. (2008). Corporate Ethical Codes: Effective Instruments for Influencing Behaviour, Journal of Business Ethics, 78(4):601-609.

[66]. Sugahara, S. and Boland, G. (2011). Faculties Perceptions of Ethics in the Accounting Curriculum: A Japanese Study, Research on Professional Responsibility and Ethics in Accounting, 15:193-224.

[67]. Svensson, G. and Wood, G. (2011). A Conceptual Framework of Corporate and Business Ethics across Organizations, the Learning Organization, 18(1):21-36.

[68]. Swanson, D.L. and Dahler-Larsen, P. (2008). Toward an Ethical Sense of self for Business Education. In D.L. Swanson and D.G. Fisher (Eds), Advancing Business Ethics Education. Charlotte, NC: Information Age Publishing.

[69]. Thorne, L. (2001). Refocusing Ethics Education in Accounting: An Examination of Accounting Students Tendency to use their Cognitive Moral Capability, Journal of Accounting Education, 19(2):103-117.

[70]. Trevino, L.K. (1986). Ethical Decision making in an Organizations: A Person-Situation Interactionist Model, Academy of Management Review, 11(2):601-617.

[71]. Valentine, S.; Nam, S.; Hollingworth, D. and Hall, C. (2014). Ethical Context and Ethical Decision Making: Examination of an Alternative Statistical Approach for Identifiable Variable Relationship, Journal of Business Ethics, 124:509-526.

[72]. Walker, M.; Paletta, D.; Blackstone, B.; Gongloff, M. and Vieira, P. (2011). Global Crisis of Confidence, Wall Street Journal, 258(37):1-10.

[73]. Weaver, K (2007). Ethical sensitivity: State of knowledge and needs for future research, Nursing Ethics,13(2):141-155

[74]. Weber, J. (2006). Implementing an Organization Ethics Program in an Academic Environment: The Challenges and Opportunities for the Duquesne University Schools of Business, Journal of Business Ethics, 65(1):23-42. 